\title{
Review \\ From Research Ethics to Researching Ethics in an Online Specific Context
}

\author{
Sari Östman * and Riikka Turtiainen \\ School of History, Culture and Arts Studies, Faculty of Humanities, University of Turku, 28100 Pori, Finland; \\ E-Mails: sari.ostman@utu.fi (S.Ö.), riikka.turtiainen@utu.fi (R.T.) \\ * Corresponding author
}

Submitted: 28 January 2016 | Accepted: 31 August 2016 | Published: 10 October 2016

\begin{abstract}
Along with the rise of a research field called digital humanities, online specific research ethics plays an especially significant role. Research on the same (Internet related) topic is usually multidisciplinary, and understanding research ethics even inside the same research community may vary essentially. It is important to recognise and pay attention to online specific contexts as well as the researcher's own disciplinary background. In this empirical research paper, we will first sum up our previous work. Currently, we are working on a model which will help in positioning multidisciplinary researchers as ethical actors based on their research topics and backgrounds. In this article, we will present this model with a demonstration of the empirical data collected as part of a Finnish research project called Citizen Mindscapes, which concerns the cultures and history of Finnish discussion forums. We argue that in Finland, and probably also worldwide, online research ethics is in a phase where the focus should be moving from defining the ethical guidelines to studying research ethics as such. We will also discuss how the model will be further developed in an in-depth empirical process.
\end{abstract}

\section{Keywords}

digital culture; digital humanities; Internet; online specific research ethics; online studies; research ethics

\section{Issue}

This review is part of the issue "Successes and Failures in Studying Social Media: Issues of Methods and Ethics", edited by Epp Lauk and Niina Sormanen (University of Jyväskylä, Finland).

(C) 2016 by the authors; licensee Cogitatio (Lisbon, Portugal). This article is licensed under a Creative Commons Attribution 4.0 International License (CC BY).

\section{Introduction}

As an online researcher, how do you understand the ethical research process? Do you work in a field where research ethics is being taught starting the first years of your university studies? Or did you, as a junior researcher, have to stumble your way through your first online specific research process trying to recognise and solve the ethical questions by yourself? Or, maybe you are from a discipline in which ethical questions are not a major concern?

We have worked with research ethics for years; teaching, publishing, developing Finnish understanding about online specific research ethics (see Turtiainen \& Östman, 2013). In Finland, research ethics and online studies are both quite novel objects to academic interest (Pekkala, 2000). Until now, the ethical interest in Finland has mainly concerned creating guidelines for conducting online-related research. However, such guidelines have existed internationally for at least 15 years (Ess, 2002; Baym \& Markham, 2009; Markham \& Buchanan, 2012) and the Finnish ones have not differed from those significantly (Kuula, 2006; Turtiainen \& Östman, 2009).

In the rise of digital humanities, online specific research ethics has also come to a situation where these basic principles become as important as ever. Simultaneously, we need to pay attention to new ethical aspects: digital humanities bring together researchers from multiple various disciplinary backgrounds, which 
means multiple ethical backgrounds. We work in the project Citizen Mindscapes (CM24) ${ }^{1}$, which brings together researchers, among others, from the following disciplines: sociology, psychology, digital culture, computer science, language technologies, statistics, anthropology and history. All of these researchers have rather varied opinions about which kind of ethics should be followed when studying Suomi24, Finland's oldest and largest online discussion forum. Östman is the responsible researcher in a work package, which concerns research ethics. Among the project, we have noticed that in order to create new, multidisciplinary understanding about online specific research ethics, we need to make it so that ethics is the actual object of research. Therefore, we are moving on from our previous work with developing online specific research ethics to researching online research ethics. In this report, we question: Which kind of variety of ethical viewpoints exists in a multidisciplinary, online specific research project? With this question, we will start mapping the field out for how the ethics can be studied.

Our current data is preliminary and comprises 16 answers to an open-answer survey in a project consortium seminar in May 2016. We asked the participants about their disciplinary background, their understanding and experiences of research ethics and the ethical challenges and questions in their current research situation.

While teaching and publishing about research ethics, we have developed certain self-reflexive methods for (novice) online researchers. We understand ethics as passing through the entire research process from choosing the subject to reporting and societal discussion. Therefore, it is also combined with every stage of the process and, in our opinion, especially with source criticism. In this report, we will present one of these methods which combines ethics with source criticism. This is an important aspect in qualitative online research (Baym \& Markham, 2009, pp. xii-xv). At the end of the report, we will tie the benefits of this method to our current findings.

First, however, we will discuss the understanding of research ethics among digital humanities. We will consider the linkage between ethics and methodology, especially source criticism. Then, we will present the story-method and 'room board' which reminds one of certain basic principles in online specific research ethics. At the end, we present a model for organising and pre-analysing the data collected from the CM24 participants. Finally, we will briefly discuss how these findings seem to lead us towards a new ethical paradigm studying the ethical processes themselves.

\footnotetext{
1 The project is funded by the Academy of Finland's Digital Humanities Programme. About this, see: Academy of Finland grants funding for Citizen Mindscapes in a Social Media project: https://www.uef.fi/en/-/suomen-akatemia-rahoittaa-kansakun nan-mielenliikkeet-sosiaalisessa-mediassa-tutkimusta
}

\section{Digital Humanities}

First, we will briefly introduce the concept of digital humanities. The term has gained extensive visibility in the academic societies in the Northern countries during the last couple for years. It was coined in the early 2000s, although it has not been possible to pinpoint it to any specific researcher or discipline. In 2010, however, the Professor of English Literature, William Pannapacker, announced digital humanities to be 'the next big thing' in research, since the digital technology had affected every possible discipline. A year later, he continued this argument on his blog in The Chronicle of Higher Education by writing that actually there is no 'next' to that; and, that very soon digital humanities will only be 'the humanities'. (Pannapacker, 2011; see also Spiro, 2012, p. 16). A mere year after that, media and communication researcher David Parry (2010) blogged about how digital humanities would fundamentally challenge all of the current humanistic research.

According to the researchers of digital culture, Jaakko Suominen and Anna Haverinen, holistic change was strongly linked to the discourse about the digital revolution at the end of the 1990s. At that time, several projects were started which, for example, aimed at digitalising humanistic research material. In addition, tools for computer-assisted production and handling of data were developed. (Suominen \& Haverinen, 2015).

Digital humanities was evolved in a situation where Western societies have been changing rapidly. It does not have centuries or even decades of tradition, which would have given it a stabilised definition. As Suominen and Haverinen write, it is a discipline-or an era of research-which has been actively developed by researchers. Digital humanities lives and further evolves along with the technologies applied in the current societies. (Suominen \& Haverinen, 2015).

There are at least two separate ways of defining digital humanities: for example media theorist Gary Hall as well as media and technology researchers Leighton Evans and Sian Rees see it as humanistic research appropriating information technological methods, which in their opinion is not necessarily a good thing (Evans \& Rees, 2012, p. 29; Hall, 2013, pp. 2-3, 133134; see also Suominen \& Haverinen, 2015). The other orientation emphasises a wider understanding about the current, digitalised culture; it includes theorising the digital world more than just applying computerassisted methods in producing and analysing the materials. (Suominen \& Haverinen, 2015). Our understanding follows the latter orientation. In positioning ourselves in the field of digital humanities, we have utilised Suominen and Haverinen's model (Figure 1) for evaluating the relationship of the researcher/research project with digitality. The model is based on the two orientations mentioned above, and on whether the research in question emphasises digitality itself as mak- 
ing and developing things or as a theoretical understanding about the digitalised world.

According to Suominen and Haverinen, this coordination might help to define any researcher's or project's, even networks' or consortiums' (e.g. CM24), internal relationships concerning digitality. This would be of significant help especially in multi-/interdisciplinary research. (Suominen \& Haverinen, 2015). As researchers of digital culture, we would position ourselves quite far on the right, more in the top than the lower corner; however, the vertical position depends extensively on every current research topic and may, therefore, vary a lot. It is also possible for us to move up and down as well as left and right on the axels according to the stage of research, even inside an individual project. After all, the division between the practical and theoretical digital humanities is not biased as much as a moving line.

With our main focus more on the understanding end, we are conducting research which quite often involves human beings either as subjects or informants of the study. In addition, we see the Internet and digitality as a research environment that ethnologists might call the field. Ethnographical methods are often applied to these kinds of studies. It is especially in these cases, but also with other kinds of methods, that ethics is extensively intertwined with methodology. Next, we will discuss what we mean by this.

\section{Self-Reflexive Ethical Tools for Digital Humanities}

In the English-speaking academic world, online studies have existed since the early 1990s, and less than a decade later, online specific research ethics was also taken into account (see Baym \& Markham 2009, pp. viii-ix). In Finland, however, research ethics in general only became an object of interest in the 1980s, but it did not get much attention until the 1990s (Pekkala, 2000). The Internet generalised in Finland since c. 1995, and only started to appear in research more widely a decade later. Since it is becoming increasingly more common to Finnish scholars to publish internationally, we need to update our late-born understanding of the online research ethics and further develop it. This is what we are aiming at in the CM24's ethics-related work-package. This further work, reaching for studying ethical processes as such, will also be generalisable more widely; we find this approach beneficial for multiple disciplinary backgrounds in international academic cultures.

The challenges that the traditional Finnish disciplines had to face due to this novelty, the Internet where people shared and lived their lives, became clearly visible to us around 2008. At that time, we were working on our online-related doctoral theses in Digital Culture. In 2008 and the coming years, we got several

\section{Axis of Digitality \& Humanities}

\section{Digitality as a subject of study}

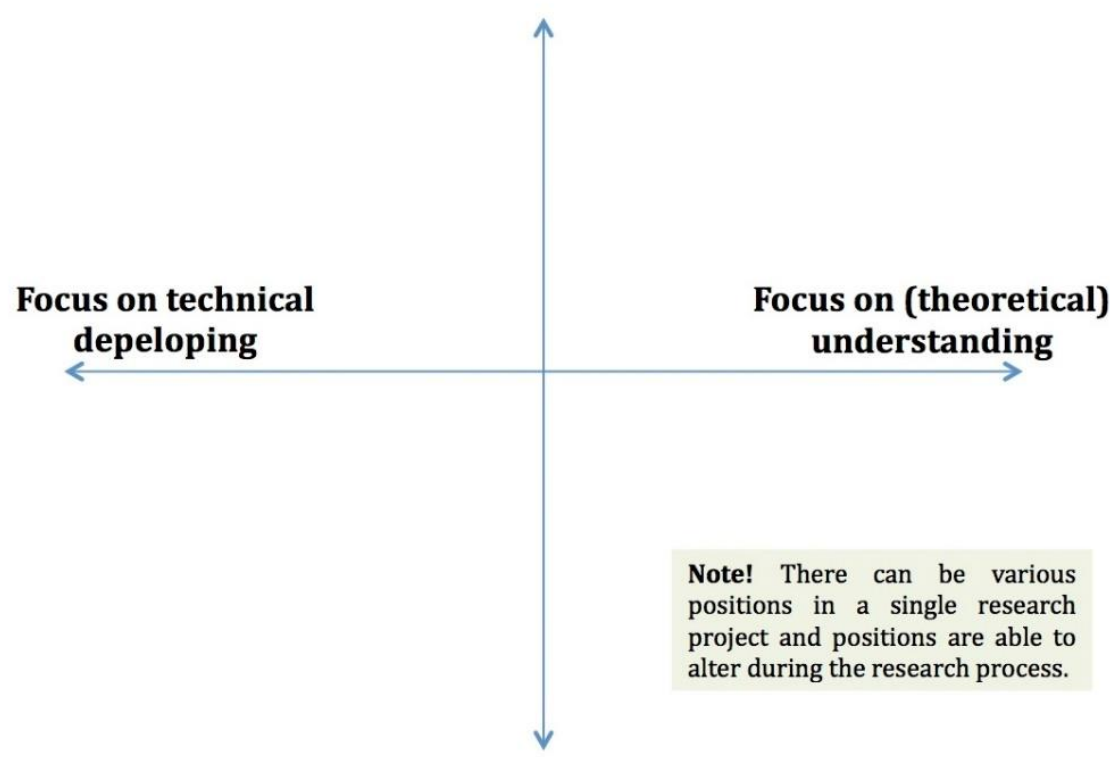

Digitality as a tool of study (research methods, methods of presentation of results etc.)

Figure 1. Model for positioning yourself among Digital Humanities research. Source: Suominen \& Haverinen, 2015 (S. Östman \& R. Turtiainen, Transl.). 
questions from doctoral students, lecturers and researchers from other disciplines (for example ethnology, anthropology etc.) concerning online studies. We were asked, for example, on what conditions we could trust our informants to be what they claimed to be; we were confronted about asking people's permission for studying them. It seemed to be a common idea that when people voluntarily published pieces of their lives online, these lives could be used for research without questioning their publicity and authors' right for the contents they had created.

On the Web, everything builds to the context: how the sites are built, what they are used for, who uses them, how the users communicate, how they feel about their contents...these elements vary a lot. Not knowing enough might lead to misinterpretations or (unintended) disrespectful usage of material (see Aull Davies, 2008; Ess, 2002). We have created a tool with certain basic principles for online researchers: 'a Room Board of Ethics' (Figure 2): in it, we ask whether the In- ternet is your tool, source or subject; are you conducting research with, on or about the Internet. Depending on your relationship to the Internet as a researcher, the Internet might be your research environment in a way which in ethnographic studies might be called the field. In these cases, it should also be seen as any other ethnographical field: you need to get hands-on experience in order to understand its mechanisms.

There are some tools for essential ethical consideration. The question of whether something can be used freely or more carefully lies at the bottom. Asking for permission, rights for citing, identities of informants/subjects to research and so on seem to be important ethical matters even still in 2016. Malin Sveningsson and others have presented in Att fånga nätet. Kvalitativa metoder för Internetforsking (To Study the Web. Qualitative Methods for Internet Studies, Sveningsson, Lövheim, \& Bergquist, 2003) a coordination system (Figure 3 ) to which researchers may position their subject, informants, material and so on,

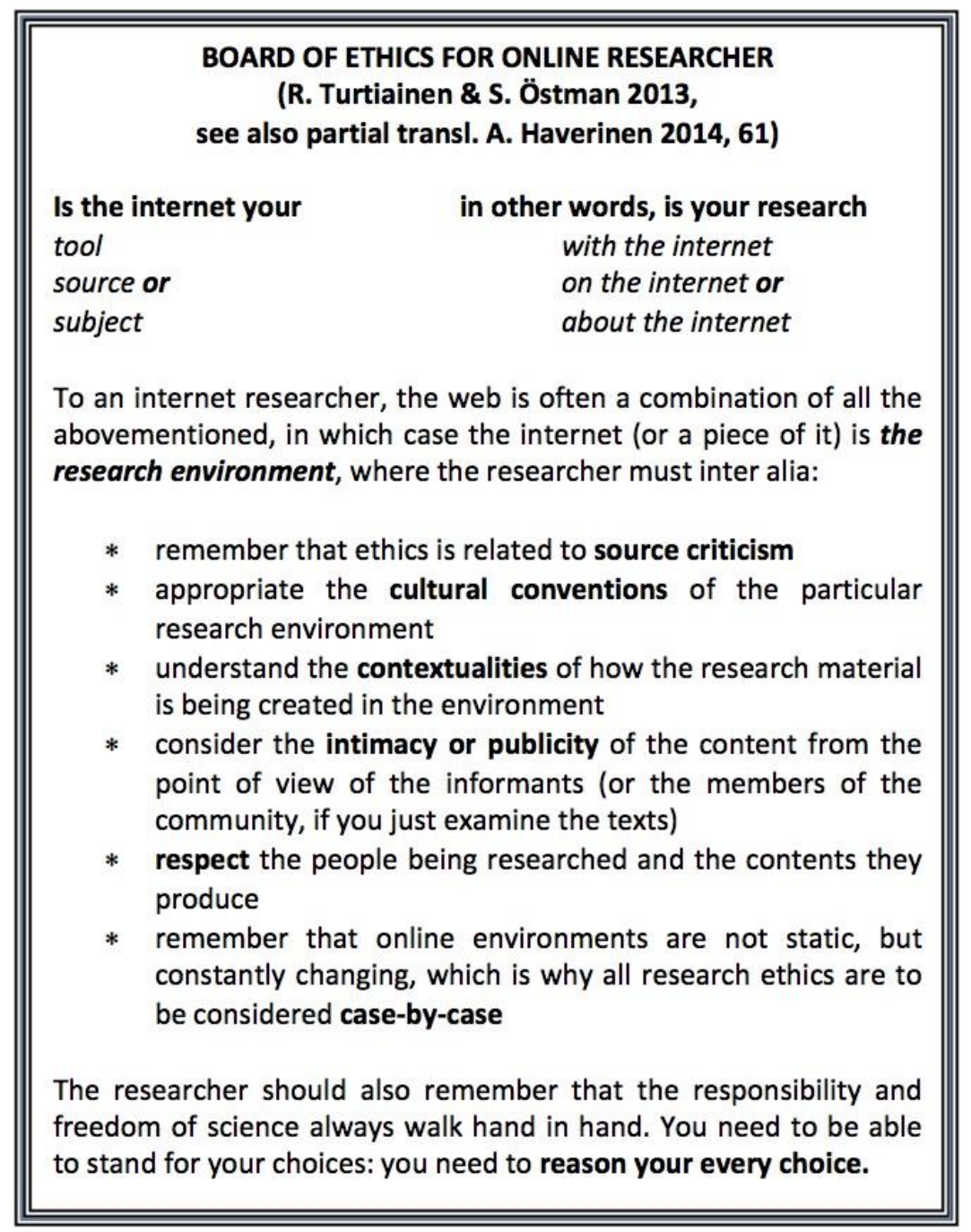

Figure 2. The Roomboard of Ethics: Some guidelines and basic principles for online research (See also Turtiainen \& Östman, 2013). 


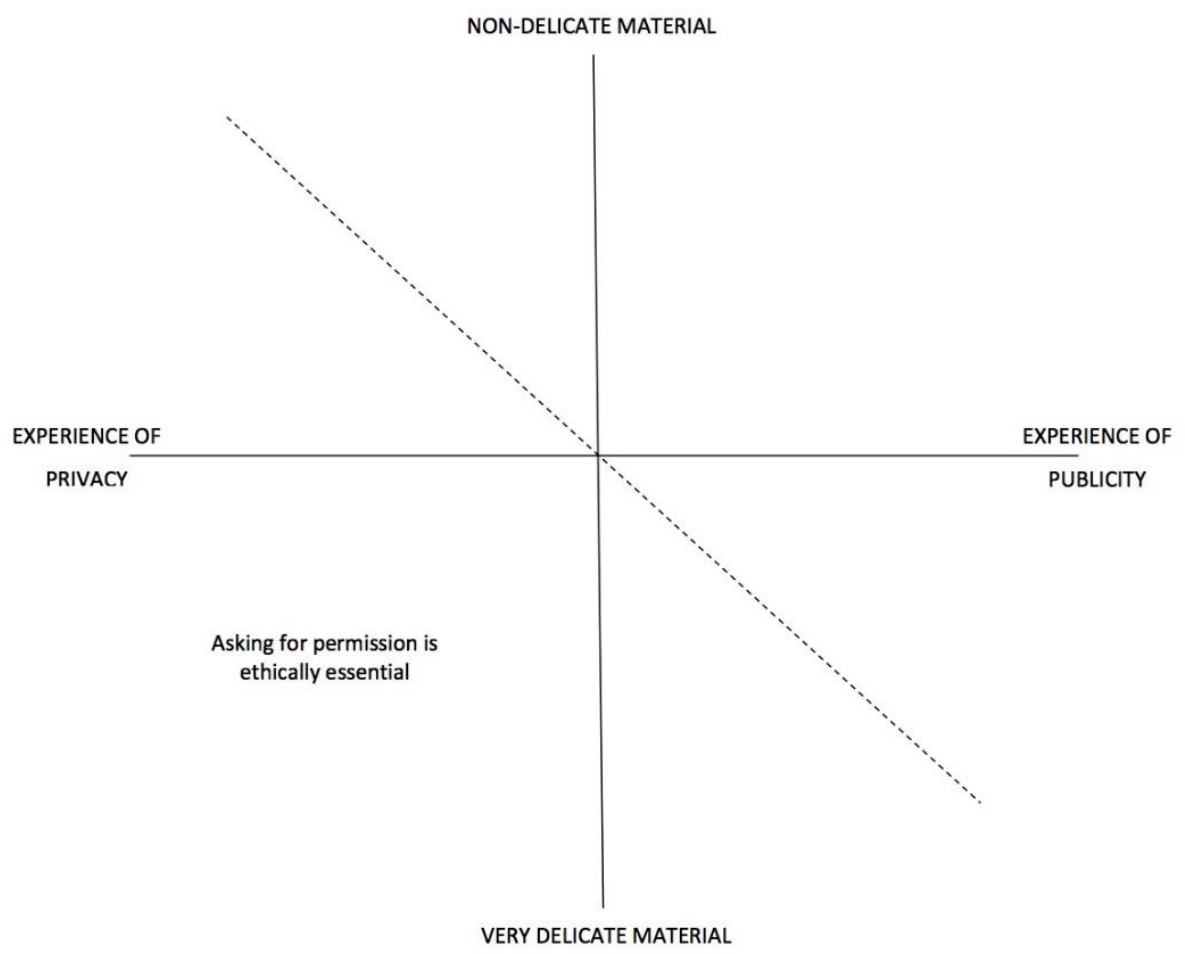

Figure 3. Delicacy of the material. Source: Sveningsson, Lövheim and Bergquist, 2003, p. 186 (the figure has been applied for example by: McKee \& Porter, 2008, p. 73, 2009, p. 11; Turtiainen, 2012, p. 52; Östman, 2015, p. 74).

according to how delicate the material is (to a reader) and how private or public the creators consider it. This most probably requires contact with the authors-or at least an extensively thorough reading by the researcher in order to learn the authors' understanding about their actions and culture: this understanding might only exist implicitly in their media texts. Either way, Sveningsson's method is very useful.

We recommend Sveningsson's model for any researcher whose data consist of users' personal online contents. This tool, however, does not offer a practical walk-through of the ethical decision-making process as an entity. For that, we have developed a story-method which has proved useful among Digital Culture undergraduates as well as graduated, but still novice online researchers.

\section{4. 'Mary's Mistakes'-A Method for Recognising Online Specific Ethical Matters}

'Mary's mistakes' is a method that we have built for recognising ethical challenges in online specific studies. It is a story with as many ethical dilemmas as possible, for which Östman invented a prototype some years ago for teaching. We developed this idea further in our Finnish article in 2013, and Turtiainen has been using the final version of the story in her teaching ever since. We find Mary's story internationally useful, since it can be applied to any individual case of research, at least in digitally oriented cultural studies. It is our further aim to find out whether or not a similar tool would work in other contexts among Digital Humanities as well (such as extremely theoretical or strictly quantitative/statistical disciplines).

Mary ${ }^{2}$ is writing her master's thesis in psychology. She wants to study eating disorders with girls. Her research question is: 'Which body images do 13-15 year old girls with an eating disorder have?' The subject is delicate, and Mary fears that volunteers are hard to find. She studies Digital Culture as a minor, and by linking her study to that, she finds a solution: Mary decides to use some pro-ana ${ }^{3}$ discussions and blogs she found on a random discussion site. Mary has had an eating disorder, but has never participated in any Internet activity about it. Actually, she does not use social media almost at all. For her study, she creates a fake profile to the site, with the nickname 'Thinspy-98'. 98 in a nickname usually refers to the birth year-Mary was born in 1991. With this nickname, she starts discussions, asking and commenting, wishing that this way she would get material for her study.

'Mary' has built for herself a great number of traps in the story: for example, her question does not quite

\footnotetext{
2 Mary is a fictional character to whom and whose study we have gathered as many ethical problems as we could think of on the basis of the questions we obtained from researchers from other disciplines.

3 'Pro-ana' refers to culture in which people with anorexia nervosa consider themselves not ill, but rather willingly choose this life-threatening lifestyle.
} 
match her chosen material; the subject is very delicate as well as the informants, who are teenagers with a severe illness; she has not thought her methods through thoroughly enough (online material is not necessarily the best choice for studying experience); she plans on cheating her informants with the fake profile; she is not going to ask for their permission; she is studying a subject very close to her; yet, she does not know anything about the environment in which she is going to produce her material.

An experienced online researcher might easily recognise all of Mary's traps. For example, in online environments, it is essential to know something about the context: who is using the site, what was it built for, which kind of conventions and habits are there (e.g. are old users and 'newbies' ${ }^{4}$ equally allowed to speak up-usually they are not), which kind of tone of voice is usual there, which aims and needs do the users have (e.g. peer support, encouraging others, asking for help, sharing own experiences...) and so on. All these aspects affect the discourse, which is unique on every site, even if they cover the same subject. Knowing the field you are working; knowing who is speaking, what they are saying, to whom, how and why they say it the way they do is basic source criticism, especially in ethnographically emphasised research.

Moreover, every case of research is unique and includes multiple different ethical dilemmas. Writing down your intended research process - for example into a story like this-may help to recognise the casebounded ethical matters. Mary's story has proved useful for the students in Turtiainen's yearly ethics class for digital culture students, and we also used it in a workshop for an ethnography course at the University of Turku in 2015. The learning process proceeds as followed:

1. Students read Mary's story;

2. The class analyses the story in the lecturer's guidance piece by piece until the class has recognised every ethical risk in the story;

3. The students write their own stories about their bachelor's/master's/doctoral theses;

4. In the course exam, they are given back their own stories for analysis, similar to which the class did together earlier with Mary's story.

The story method has several benefits. It forces the researchers to be self-reflective, which helps them in positioning themselves in relation to the subject as well as practising sustainable source criticism. The doctoral students in our ethnography workshop found this method very useful: in their feedback, they described it as practical, illustrative and eye-opening. Some of the students had not recognised the current challenges,

\footnotetext{
${ }^{4}$ New users.
}

but also understood why certain earlier processes or phases had not succeeded. A doctoral student wrote:

'I found the workshop really useful considering my doctoral studies and future career as a researcher. Especially, I'm thankful for the concrete examples with which both the lecture and the workshop demonstrated the ethical questions that we might face in the research process.'

Next, we will move on from online specific research ethical tools for researchers; we will proceed to discussing the possible tools for actually studying these ethics. By applying our model to preliminary CM24 data, we will aim at finding out how ethical viewpoints vary among a multidisciplinary project. The next steps after this pilot study will lead us towards creating some commonly applicable guidelines for such widely multidisciplinary projects.

\section{Towards Studying Research Ethics}

The coordinate system that we presented in the beginning (Suominen \& Haverinen, 2015), was suggested to be utilised for scholars to position themselves according to their research focus and motives. This model is a great start for positioning yourself on the field of online studies. It also has inspired us in developing a tool for studying various ethical approaches (Figure 4). We collected some preliminary data in a CM24 consortium seminar in May 2016. Östman asked the seminar participants to answer the following questions:

1. Disciplinary background and current research;

2. Describe your understanding about research ethics and/or ethically conducted research; which matters do you find the most essential; what kinds of things have affected your understanding?

3. Which ethical questions and/or practices do you expect to face during your current research; how do you plan to proceed with them?

We obtained 16 answers, one of which could not be integrated to our model. We have coded the answers as P1-P15 ( $P$ = Participant). The participants came from multiple disciplinary backgrounds, and they integrate into our model (see Figure 4).

The basic idea of this fourfold table is based on Suominen and Haverinen's figure. We have further developed it on the basis of our roomboard: in it, we defined a researchers' relationship with the online environment as being threefold: it may be a tool, a subject or a source for the study. In this example (Figure 4), we have specified 'online environment' as the Suomi24 discussion forum, which is the focus of the whole CM24 project. Our former studies have shown that the more focal the online environment is and the more understanding the manner of research, the more 


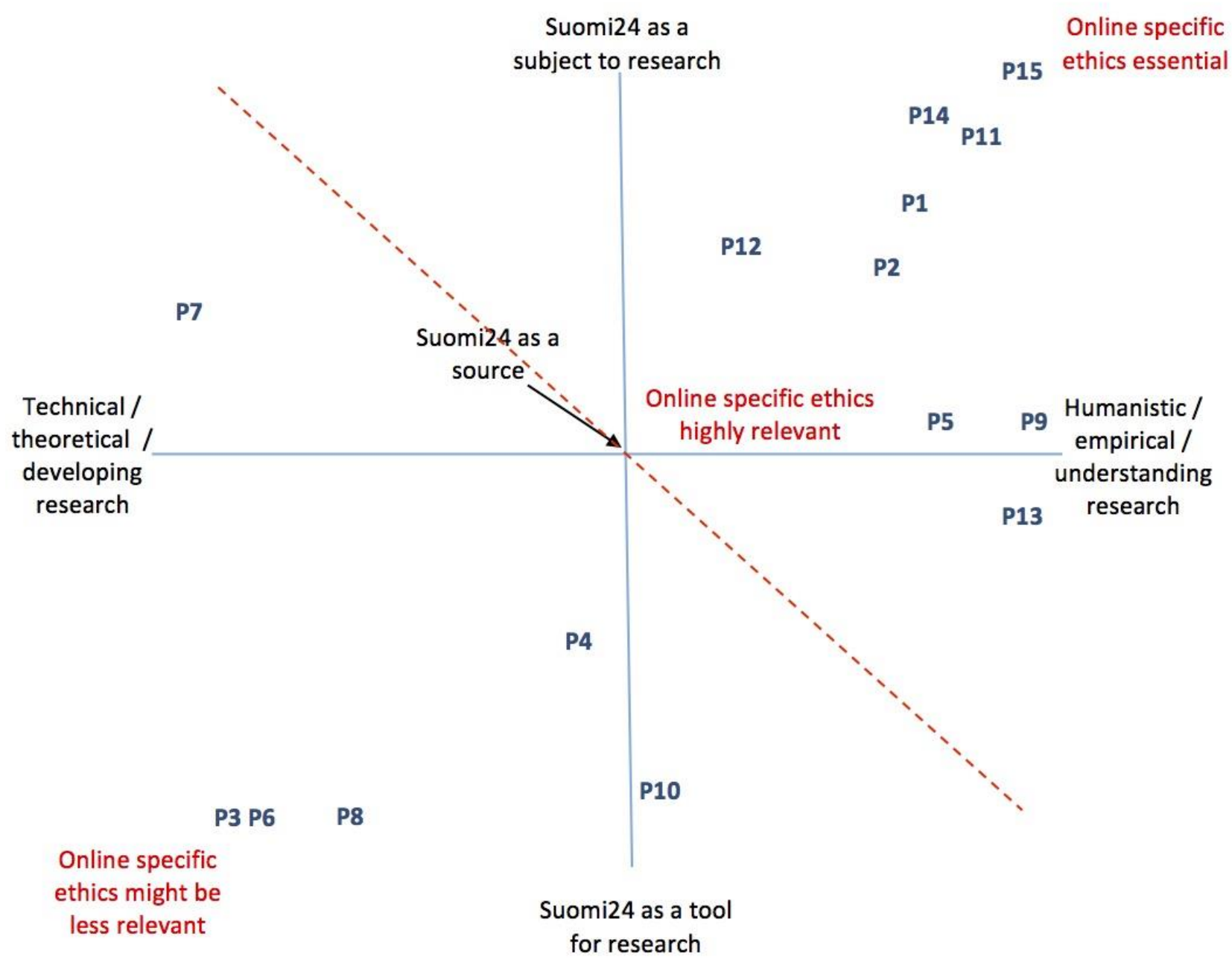

Figure 4. Online environment (Suomi24 discussion forum) in multidisciplinary research.

relevant, even essential, it is to take online specific ethics into account (Östman \& Turtiainen, in press).

In Figure 4, the participants P3, P4, P6, P7, P8 and $\mathrm{P} 10$ represent quantitatively and statistically oriented disciplines and backgrounds ${ }^{5}$. According to their survey answers, they are situated below the line, which defines the relevance of online specific ethics. Among those, an online specific take to ethics might not be that necessary, which was well articulated in their answers. With their background, ethics mostly have to do with such matters as copyright laws (P3, P7) and open access to the data: 'Privacy protection might be in contradiction with what could be learned from the data' (P4).

Participants P1, P2, P5, P9, P11-P15 are situated above the relevance-defining line. They come from humanistic backgrounds and tend to have humanrelated, understanding and in several cases, culturally oriented research take: Will my analysis do justice to

${ }^{5}$ In order to keep answers anonymised, we cannot specify the individual disciplines. the data; that is, will it give a right kind of a voice to the participants?' (P5). They answered the survey more thoroughly and seemed to have a wider understanding about the research ethical processes; some of them had been taught ethics in their university studies, whereas the first group (below the line) had not been educated about ethics and tended to see it more as legal points rather than decision-processes. However, multidisciplinary research environments helped the participants to appropriate a more reflexive, process-oriented ethical take. P12 had their background in information technology. However, he/she saw their multidisciplinary experience and discussions as an ethically evolving actor, which had led to a reflexive ethical approach.

To be able to consider all the facts needed for ethical decision-making in a multidisciplinary process, the researcher needs to understand at least these three things; the contexts, the research environment and their own background (of importance of recognising the contextual specificities see also Nielsen, Paasonen, \& Spisak, 2015, p. 11). Doing this, we suggest that indi- 
vidual researchers, even those situated in the low left corner of our tool, might benefit from a case-based self-reflexive ethical analysis such as 'Mary's mistakes' method. The next step of our study will include engaging these participants to apply Mary-method in their own case studies. This will be done in the next consortium seminar in fall 2016. By analysing the results of that step, we will find out whether the ethical counderstanding of a multidisciplinary project will benefit from this kind of case-based learning. Simultaneously, we will further proceed in this new field of studying online specific research ethics as its own entity. Based on this process, we would like to suggest that in Finland, possibly also worldwide, a shift of paradigm from research ethics to researching ethics is about to appear.

\section{Summary}

In this article, we have presented a) a tool to researchers for positioning themselves in the field of Digital Humanities (Suominen \& Haverinen, 2015), b) a method for contextually reflexive ethical decision-making and certain basic principles for that, and finally c) a tool for studying the actual ethical decision-making processes. By leading researchers to actively consider their ethical approaches, we will be able to study research ethics and its practical applying-processes in multiple disciplines. By doing this, we aim at creating a commonly functional and effective guideline for online specific, widely multidisciplinary research. The follow-up for this preliminary study will be carried out in fall 2016 (Step 2: Marymethod) and 2017 (Steps 3 and 4: undefined ${ }^{6}$ ).

\section{Acknowledgements}

The article is part of the Citizen Mindscapes project which is funded by the Academy of Finland.

\section{Conflict of Interests}

The authors declare no conflict of interests.

\section{References}

Aull Davies, C. (2008). Reflexive ethnography. A guide to researching selves and others. London and New York: Routledge. (Original work published 1998)

Baym, N. K., \& Markham, A. N. (2009). Introduction: Making smart choices on shifting ground. In A. N. Markham \& N. K. Baym (Eds.), Internet inquiry. Conversations about method (pp. viii-xix). Los Angeles: Sage Publications.

Ess, C. (2002). Ethical decision-making and Internet research. Recommendations from the AolR ethics working committee. Retrieved from http://aoir.org/

${ }^{6}$ In order to protect the novelty of our research. reports/ethics.pdf

Evans, L., \& Rees, S. (2012). An interpretation of digital humanities. In M. B. David (Ed.), Understanding digital humanities (pp. 21-41). New York: Palgrave Macmillan.

Hall, G. (2013). Towards a postdigital humanities: Cultural analytics and the computational turn to datadriven scholarship. American Literature, 85(4), 781809.

Kuula, A. (2006). Tutkimusetiikka: aineistojen hankinta, käyttö ja säilytys. Tampere: Vastapaino.

Markham, A., \& Buchanan, E. (2012). Ethical decisionmaking ad internet research. Retrieved from aoir.org/reports/ethics2.pdf

McKee, H., \& Porter, J. (2008). The ethics of digital writing research: A rhetorical approach. College Composition and Communication, 59(4), 711-749.

McKee, H., \& Porter, J. (2009). Playing a good game: Ethical issues in researching MMOGs and virtual worlds. International Journal of Internet Research Ethics, 2(1), 5-37.

Nielsen, S., Paasonen, S., \& Spisak, S. (2015). 'Pervy roleplay and such': Girls' experiences of sexual messaging online. Sex Education: Sexuality, Society and Learning, 15(5), 472-485.

Östman, S. (2015). 'Millasen päivityksen tästä sais?' Elämäjulkaisijuuden kulttuurinen omaksuminen (Published Doctoral dissertation). University of Turku, Pori, Finland.

Östman, S., \& Turtiainen, R. (in press). How to position yourself as an ethical researcher? Analytical viewpoints to online research ethics. In P. Hakamies \& A. Heimo (Eds.), Doing folkloristics in the digital age. Turku: Folklore Fellows Communications.

Pannapacker, W. (2011, January 8). Pannapacker at MLA: Digital humanities triumphant? The Chronicle of Higher Education. Retrieved from http://www. chronicle.com/blogs/brainstorm/pannapacker-at-ml a-digital-humanities-triumphant/30915

Parry, D. (2010). The MLA, @briancroxall, and the nonrise of the Digital Humanities. AcademicHack. Retrieved from http://academhack.outsidethetext.com /home/2010/the-mla-briancroxall-and-the-non-riseof-the-digital-humanities

Pekkala, A. (2000). Tutkijan eettiset ongelmat. In P. Laaksonen, S. Knuuttila, \& U. Piela (Eds.), Tutkijat kentällä (pp. 85-110). Helsinki: SKS.

Spiro, L. (2012). "This is why we fight": Defining the values of digital humanities. In M. K. Gold (Ed.), Debates in the digital humanities (pp. 16-34). Minnesota: University of Minnesota Press.

Suominen, J., \& Haverinen, A. (2015). Koodaamisen ja kirjoittamisen vuoropuhelu?-Mitä on digitaalinen humanistinen tutkimus. Ennen ja nyt. Retrieved from http://www.ennenjanyt.net/2015/02/koodaamisenja-kirjoittamisen-vuoropuhelu-mita-on-digitaalinenhumanistinen-tutkimus/\#identifier_14_1502 
Sveningsson, M., Lövheim, M., \& Bergquist, M. (2003). Att fånga Nätet. Kvalitativa metoder för Internetforskning. Lund: Studentlitteratur.

Turtiainen, R. (2012). Nopeammin, laajemmalle, monipuolisemmin. Digitalisoituminen mediaurheilun seuraamisen muutoksessa. (Published Doctoral dissertation). University of Turku, Pori, Finland.

Turtiainen, R., \& Östman, S. (2009). Tavistaidetta ja verkkoviihdettä. Omaehtoisten verkkosisältöjen tutkimusetiikkaa. In M. Grahn \& M. Häyrynen (Eds.), Kulttuurituotanto. Kehykset, käytäntö ja prosessit (pp. 336-358). Helsinki: SKS.

Turtiainen, R., \& Östman, S. (2013). Verkkotutkimuksen eettiset haasteet: Armi ja anoreksia. In J. Matikainen \& M. Tikka (Eds.), Otteita verkosta. Verkon ja sosiaalisen median tutkimusmenetelmät (pp. 49-67). Helsinki: Gaudeamus.

\section{About the Authors}

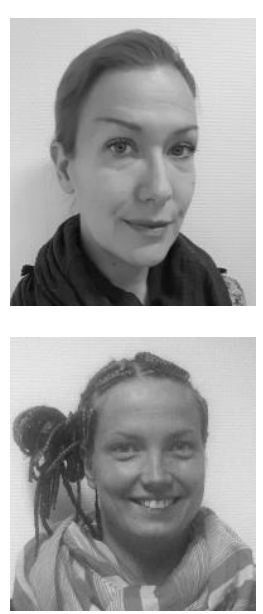

Sari Östman (PhD) is a Digital Culture researcher currently working as a researcher in the Citizen Mindscapes project at the University of Turku. She wrote her doctoral thesis (2015) about online lifepublishing. Östman has been teaching and studying online research ethics from 2009. Her other interests include online cultures and histories.

Riikka Turtiainen (PhD) is working as a University Lecturer of Digital Culture at the University of Turku. She teaches research skills: research ethics, material collecting methods, research-based thinking and creative writing. Her doctoral thesis (2012) considered digital media sports. Her current research interests focus on new aspects of sports cultures, social media and online research ethics. 